\title{
The Development of E-Learning Based Instructional Model in Learning English
}

\author{
Lona Marlina \\ Educational Technology, Postgraduate Program \\ Universitas Negeri Medan \\ Medan, Indonesia \\ lonamarlina.lm@gmail.com
}

\author{
Efendi Napitupulu \\ Educational Technology \\ Universitas Negeri Medan \\ Medan, Indonesia
}

\begin{abstract}
In the current era of globalization, the development of technology is very rapid. Basically the concept of educational technology is still focused on efforts to give solution of learning problems. In accordance with the development of education and learning at this time, one of them is learning in electronic form or commonly called as e-learning. The development of e-learning based instructional model is very helpful and facilitates the learning process. This study belongs to a research and development which uses the R\&D model by Borg and Gall and combined with the instructional design model by Dick and Carey. With the concept of modern learning, it is expected to combine the software and hardware intelligence in the world of education. The existence of e-learning can not be separated from computer and internet. This concept backs the use of e-learning based instructional model which has been developed. The result of this study indicates that the instructional model is proper to use in learning English.
\end{abstract}

Keywords—instructional model, e-learning, english

\section{INTRODUCTION}

The improvement of education quality is a major priority in developing the education nowadays. Some efforts that the government does to reach the purpose of education are improving the human resources and non-human resources. One of them is to improve the instructional process. Instructional process is a system because certainly the source of instructional success at school is connected to the components involved in it. The components are curriculum, strategy, model, teacher, media, method, students and everything involved in the instructional process and the education.

The use of instructional media must be considered in the instructional process because it determines the mastering of matter taught by the teacher. The instructional media can improve the result of students' learning outcome. Muhadi [1] said that media is really needed in the instructional process because media is teacher's language to deliver the teacher's feeling and meaning to the students. Through media, students can understand easily what the teacher delivered in the instructional process.

The development of technology nowadays can support the instructional process. Based on this approach, an instructional media can be designed. The adaptive media is really useful in the future as a new paradigm in instructional process and it can give a space with an innovative tool to fulfill the students' need in which it can't be done before. The existence of computer nowadays can't be used effectively to improve the students' achievement, especially in the instructional process. During the instructional process, teachers use the lecturing method classically. Teachers don't use an alternative media instead of text books. This instructional method doesn't understand the effective instructional principles and it doesn't also empower the students' potential. The learning activities should be able to optimize the students' potential to master all the students' competences to get the expected competences.

The mastering of English in Senior High School, especially for the Vocational High School students is really pushed to produce the great graduated students with competitive skill in the global era. Education can improve the quality of instructional process and product in Vocational High School, especially to change the instructional paradigm to be more innovative and constructive in the dynamics of technology development. It is needed to create a learning environment which can attract the students' interest. The tools and infrastructures in learing must be designed to create an innovative, effective and efficient instructional process.

One of the major activities in the instructional process is learning activity. The success of the education objectives is depended on how the learning process runs effectively or not. Beside that, the teacher's understanding toward the meaning of learning can affect the teacher's way to do the learning activities which finally it affects the aspect of students' intellectual, psychology and biology.

According to Sumantri [2], learning is the change of attitude which is relatively permanent and as the result of the past experience or the purposeful and planned instruction. According to Budiningsih [3], learning based on the constructivist view is a process of making knowledge. The making process is done by the students to do some activities and think to arrange the concept and matter which is learned.

The instruction in this study used e-learning based isntructional model with the application of "Sway". Sway is an application with the cloud storage. The users can save their content to connect to any tools and social networks. On the other words, sway can be used to replace Power Point. Sway has a function to show the content in modern way. The users don't need to have a program. This application can make the 
users be easy to upload the content from all applications they use , such as One Drive or Facebook, then they can create a presentation from the content. Microsoft said that they can add more sources of content and new ways to interact with the content. Waller dan Wilson [4] said that electronic learning or e-learning has been started since 1970 but it has been commercialized and developed sich 1990. According to Kamarga [5], e-learning is the application of newly information technology in Indonesia. It has been known commercially in 1995 when Indo Internet opened its service as the first provider of internet service. E-learning consists of two parts, they are "e" which means "electronic" and "learning" which means "instruction". So, e-learning is an instruction which uses electronic devices, especially computer. Accroding to Darmawan [6], e-learning or online learning is an instruction which is supported by electronic devices such as telephone, audio, videotape, satellite transmission or computer.

\section{RESEARCH METHOD}

The method used in this study is research and development which uses R\&D model by Borg and Gall and combined with instructional design model by Dick and Carey. This research was conducted in SMK PAB 1 Helvetia toward the tenth graders of Multimedia class in the learning year of 2018-2019. This research was started by doing observation at the school to know about the total of the students, their background, the teachers' experience, tools, infrastructures and the condition of the classroom. This research was conducted in Multimedia class only which has two classes with 32 students in each.

The target of this study is the development of e-learning based instructional model in learning English. The developed media contains of matter and evaluation which are based on the students' need and competence they have to get. The subject of this reasearch is the tenth graders.

To produce the proper roduct, there are some steps that the researcher should do, as follows:

a. Validate the product to instructional design experts, media experts and instructional content experts.

b. Do the individual trial toward 3 students.

c. Do the small group trial toward 9 students.

d. Do the field trial toward 32 students.

The data in this research and development is qualitative and quantitative data. The qualitative data is a written comment and suggestion given by the instructional design, media and content experts, and also by the students as the users. The instrument is a questionnaire. The scale of the assessment is 1 to 5 with the criteria: (1) very poor, (2) poor, (3) enough, (4) good, and (5) very good.

The properness of the product can be analyzed with the pattern below:

$$
\mathrm{X}=\frac{\text { Total Score }}{\text { Idea] Total Score }} \times 100 \%
$$

The criteria of the assessment can be seen in Table 1 .

TABLE 1. THE CRITERIA OF ASSESSMENT

\begin{tabular}{|c|c|c|}
\hline No. & Score & Criteria \\
\hline 1. & $86 \% \leq X \leq 100 \%$ & Very Good \\
\hline
\end{tabular}

To ensure the effectiveness of the product, the researcher did the effectiveness testing through t-test. The data analysis in this study used quantitative data analysis technique. $76 \% \leq X \leq$ $85 \%$ is good, $66 \% \leq X \leq 75 \%$ is enough, $56 \% \leq X \leq 65 \%$ is poor and $0 \% \leq X$ $\leq 55 \%$ is very poor

The pattern of t-test is:

$\tau=\frac{\bar{X}_{1}-\bar{X}_{2}}{\sqrt[5]{\frac{1}{n_{1}}+\frac{3}{m_{2}}}}$

\section{RESUlt AND DisCUSSION}

TABLE 2. PERCENTAGE ASSESSMENT RESULTS BY EXPERTS LEARNING MATERIALS BASED ON E-LEARNING

\begin{tabular}{|c|c|c|c|}
\hline NO. & Categorization & Percentage & Criteria \\
\hline 1 & $\begin{array}{ll}\text { Guidance } & \text { dan } \\
\text { information } & \\
\end{array}$ & $96 \%$ & jood \\
\hline
\end{tabular}

The average of table is known that the total percentage of material expert ratings of all subjects is $96,1 \%$ (multimedia content $97,69 \%$ and evaluation $92,5 \%$ ) which is included in the very good evaluation criteria.

TABLE 3.PERCENTAGE OF EXPERT ASSESSMENT E-LEARNING BASED LEARNING MEDIA

\begin{tabular}{|c|c|c|c|}
\hline No & Categorization & Percentage & Criteria \\
\hline 1 & Guide and Information & $93,33 \%$ & Very Good \\
\hline
\end{tabular}

From the table is known that the percentage of media expert ratings from all aspects is 93,,44\% (guide and information 93,33\%, operasional multimedia $95 \%$ and systematics, aesthetics and media design principles 92\%) which is included in the very good evaluation criteria.

TABLE $4:$ AVERAGE PERCENTAGE OF ASSESSMENT OF LEARNINGDESAIN EXPERTS CRITERIA

\begin{tabular}{|c|l|c|c|}
\hline No & Percentage of Assessment & Percentage & Criteria \\
\hline 1 & Assessment Aspects & $93,57 \%$ & Very Good \\
\hline
\end{tabular}

From the table above, it can be seen that the average percentage of percentation quality with a value of $95,28 \%$ (assessment aspect 93,57\%, content 98\% and graphic 94,28\%) are included in the very good category, which means the presentation of this e-learning based learning model has an attractive appearance so that it can attract students to learn it.

The results of individual trials on e-learning of learning media in the developed English language lessons show that the media already have to covering guidance and information aspects with a score of $93,33 \%$, aspect of media materials $92,31 \%$, evaluation aspects $93,33 \%$, aspects media design and facilities $93,33 \%$, and pedagogical aspects $96 \%$.

From the average percentage of the results of research on learning models of English subjects in a small group test of $94,90 \%$ with the criteria very good. The aspects of guidance and information $96,11 \%$, the material aspects of the media 
$94,87 \%$, the evaluation aspects $95,11 \%$, the design aspects and media facilities $93,78 \%$, pedagogical aspects $96 \%$.

The result of the limited field trials of the learning media from the aspects of guidance and information to $95,93 \%$, aspects of media materials amounted to $95,05 \%$, evaluation aspects $93,13 \%$, design aspects and media facilities were $94,25 \%$, and pedagogical aspects were $95 \%$.

Based on student learning outcomes taught using elearning based learning models it was found that the scores of students learning outcomes from 32 respondents were spread out in the range 12-38, from the calculation results showed that the lowest score was 12 and the highest score was 38 mean 25,09, mode 22,5 median 25, standard deviation 2,94.

Based on the student learning outcomes learned without using e-learning based learning models it was found that the scores of students learning outcomes from 32 respondents were spread out in the range $11-31$, from the calculation results showed that the lowest score was 11 and the highest score was 31 , the mean 20,06 mode 22,5, median 20, standard deviation 2,94 .

TABLE 5 COMPARISON OF EXPERIMENT CLASSES AND CONTROL CLASESS

\begin{tabular}{|c|c|c|c|c|}
\hline No & Class & $\mathrm{L}_{\text {count }}$ & $\mathrm{L}_{\text {table }}$ & Conclusion \\
\hline 1 & Experiment & 0,062 & 0,157 & Normal \\
\hline 2 & Control & 0,023 & 0,157 & Normal \\
\hline
\end{tabular}

The results of student calculations performed in the experimental class for a significant level $\alpha=0,05$ optained $\mathrm{L}_{\text {count }}$ maximum 0,062. In the list of critical values of $\mathrm{L}$ for Liliefors Test by $\mathrm{n}=32$ is $\mathrm{L}_{\text {table }}=\frac{0,886}{\sqrt{n}}=\frac{0,886}{\sqrt{32}}=0,157$ because $\mathrm{L}_{\text {count }}<\mathrm{L}_{\text {table, }}$, is $0,062<0,157$, so concluded the learning outcomes data using e-learning based learning models conducted at SMK PAB 1 helvetia with normal distribution.

While the results of student calculations performed in the control class to a significant level $\alpha=0,05$ optained $\mathrm{L}_{\text {count }}$ maximun 0,023 . In the list of critical value of $\mathrm{L}$ to Liliefors Test by $\mathrm{n}=32$ is $\mathrm{L}_{\text {table }}=\frac{\mathrm{U}, 886}{\sqrt{n}}=\frac{0,886}{\sqrt{32}}=0,157$ because $\mathrm{L}_{\text {count }}$ $<\mathrm{L}_{\text {table }}$, is $0,023<0,157$, it conclude the learning outcomes data without using an e-learning based learning model, the data is concluded learning outcomes by using e-learning based learning models conducted at SMK PAB 1 Helvetia with normal distribution.

Homogeneity test is done to find out whether the data is homogeneous or not.Homogeneity testing requirements can be carried out if there are normal.To conduct a homogeneity test, in this study carried out using the Fischer Test, the sample has a homogeneous variance if $\mathrm{F}_{\text {count }}<\mathrm{F}_{\text {table }}$ significant variance $\alpha$ $=0,05$, calculated using the formula $: F=\frac{\text { Varians teroesar }}{\text { Varians terkect }}$

The amount of variance for the experimental class with $\mathrm{N}$ $=32$ is 0,843 and the variance for control class with $\mathrm{N}=32$ is 0,707 , then :

$$
\begin{aligned}
\mathrm{F} & =\frac{\mathrm{U,843}}{U_{1} / \mathrm{U} /} \\
& =1,192 \mathrm{~F}(\text { table }=1,84)
\end{aligned}
$$

From he results of the above calculation it can be concluded that $\mathrm{F}_{\text {count }}=1,192$ is smaller than $\mathrm{F}_{\text {tablel }}=1,84$ thus the sample is Homogeneous.

Hypothesis testing to test this hypothesis the t test is used:

$$
\mathrm{t}=\frac{x 1-x 2}{s \sqrt{\frac{1}{n 1}+\frac{2}{n z}}}
$$

From the calculation results obtained that the value of $t_{\text {count }}$ $=1,80>t_{\text {table }}=1,65$, therefore it can be concluded that the $\mathrm{t}_{\text {count }}>\mathrm{t}_{\text {table }}$ which means Ha is accepted, or in other words there is a significant difference between learning outcomes in the class being taught with the e-learning based model learning means that the e-learning based learning model developed can improve English learning outcomes at SMK PAB 1 Helvetia.

To test the effectiveness of the developed e-learning based learning model, the following calculations are made:

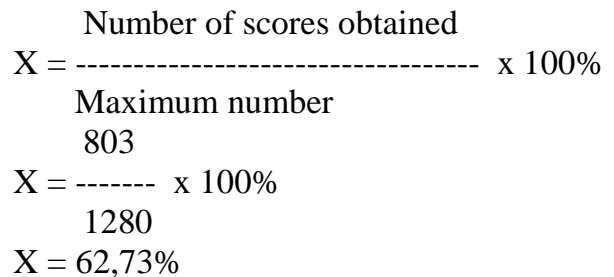

The value of learning effectiveness without using based learning models e-learning is developed, then the following calculatins are made:

Number of scores obtained

Y $=$ Maximum number

$Y=\frac{642}{1280}$ x $100 \%$

$\mathrm{Y}=50,15 \%$

\section{CONCLUSION}

At the heart of the e-learning is still for education to take place. Technology is only a tool to facilitate the processes involved. Teachers and students are still the ones who have to make teaching and learning happen. Students need to want to construct knowledge on their own instead of merely receiving and memorizing what is taught. On the other hand, teachers must have in-depth knowledge of their content and pedagogical matters. The more teachers know how their students learn, the more they will be able to employ a variety of teaching strategies and instructional models including a wide-range of technology-based tools in matching their students' needs with the content to be taught. Technologyenhanced learning environments need to be designed by 
considering pedagogy and content matters for higher ecological validity and thus for systems be useful in practice.

\section{ACKNOWLEDGMENT}

In this occasion the author expressed his appreciation and profound gratitude to head master and teachers who have supported the author in terms of morale and materil. The author also express my deepest gratitude to all parties who have helped until this paper can be complete.

\section{REFERENCES}

[1] Y. Munadi, "Media Pembelajaran, Sebuah Pendekatan Baru”, Jakarta: Gaung Persada Press, pp.5, 2008

[2] Sumantri, "Strategi Pembelajaran". Jakarta : Kharisma Putra Utama, pp. 2, 2005

[3] C. A. Budiningsih, "Pembelajaran Moral". Jakarta: PT Rineka Cipta, pp. 58,2008

[4] N. Washington, and C. G Wilson, "A Definition for E-learning".The OLD QC Newsletter, 2001

[5] H. Kamarga, "Belajar Sejarah Melalui E-learning. Alternatif Mengakses Sumber Informasi Kesejarahan". Jakarta: Inti Media, 2002

[6] D. Darmawan, "Pengembangan E-Learning Teori dan Desain". Bandung: PT Remaja Rosdakarya, pp.25, 2014 